\title{
Buddhism in Sarnath: An Account of Two Chinese Travellers
}

Dr Anuradha Singh ${ }^{\dagger}$

\section{Abstract}

This paper aims to draw the religious life in Sarnath (and Varanasi) as accounted by the Chinese travellers-Fa-Hien and Hiuen-tsang. The accounts not only talk about the stupas, pillars, statues built by King Ashoka; vihars and monks (bhikshus) living in those vihars but also contain the first preachings of Lord Buddha, establishment of Sangha and the story of Mrigajataka that remain significant. With the increased popularity of Buddha dharma in China, the Chinese were attracted towards travelling to India. They came to India mainly with the intentions to visit the places related to the fond memories of Lord Buddha, to study the Buddha religion and philosophy and carry the copies of the Buddhist compositions. Fa-Hien and Hiuen-tsang occupy significant places among these Chinese travellers. These accounts can be associated with ancient history as well as with historical geography, religion and philosophy. While Fa-hien in his journey details had described about the Buddha Empire, Hiuen-tsang highlighted the civilisation of India and its cultural landscape, albeit it has been often accepted by the historians that these accounts of their journeys should be considered as significant only when they are backed by historical evidences. They opine that these travellers were mainly influenced by the Buddha dharma and therefore, their accounts are liable to containing exaggerated journey details. It is true that the journey details contain few imaginary instances; nevertheless, these accounts have been validated by the remnants, stupas and vihars at the sites.

Key words: Sarnath, Varanasi, Dukkha, Fa-Hien, Hiuen-Tsang, Buddha

\footnotetext{
${ }^{\dagger}$ Assistant Professor, Department of History, Faculty of Social Sciences, Banaras Hindu University, Varanasi, India. Email: dr.anuradha.bhu@gmail.com

(c) 2014 Singh. This is an Open Access article distributed under the terms of the Creative Commons Attribution License (http://creativecommons.org/licenses/by/2.0), which permits unrestricted use, distribution, and reproduction in any medium, provided the original work is properly cited.
} 


\section{Introduction}

This paper is an attempt to sketch a critical appreciation of the account of the Chinese pilgrims: Fa-Hien and Hiuen-tsang on Sarnatha site for heritage tourism and one of the four holy places associated with the life of Lord Gautama Buddha-the other three being Lumbini in Nepal, Bodh Gaya in Bihar and Kushinagar in Uttar Pradesh. Sarnath, derived from the name Saranganath, means Lord of the Deer. There is a well-known Buddhist story of two deers and the 'deer park' (Mrigadava) connected to this divine place. Located near the confluence of the Ganges and the Gomati rivers, the holy place of Sarnath is approximately $13-\mathrm{km}$ northeast from the heritage city of Varanasi in Uttar Pradesh. Undoubtedly, these heritage structures dominate the subtle collective psyche of the Indians that bears identity and culture. Seemingly, the account of Sarnath as provided by the Chinese travellers make it easier to understand the development of Buddha dharma and its impact on various sects and communities. The paper begins with the first preaching of Lord Buddha, the establishment of Sangha and the story of Mrigajataka that remain significant to understanding the religious life in the holy place. The followers of Buddha dharma owe extreme faith towards Sarnath. It is known as the place of its origina place where Gautama Buddha delivered his first sermon, known also as Dharmachakrapravartansthala $^{1}$ after he attained enlightenment in Bodhgaya. He first decided to preach his five disciples, who were previously his associates. Further, he came to Sarnath and proposed the four noble truths, ${ }^{2}$ which are as follows:

\footnotetext{
${ }^{1}$ It refers to the teachings of Four Nobel Truths of Lord Gautama Buddha-the key to understanding the Buddha Dharma and the road to achieving enlightenment (Beal, 1980).

${ }^{2}$ The Four Noble Truths (2009, November 17). BBC Religions, Retrieved from: http://www.bbc.co.uk/religion/religions/buddhism/belie fs/fournobletruths_1.shtml
}

\section{Four Noble Truth}

- The truth of dukkha (suffering)

- The truth of the origin of dukkha

- The truth of the cessation of dukkha and

- The truth of leading to the cessation of dukkha.

He further laid down the eight-fold factor for salvation from dukkha, which are as follows right view, right intention, right speech, right action, right livelihood, right effort, right mindfulness, right concentration. He preached to follow the middle way (Cowel, 1893).

After this event, Sarnath emerged as a centre out of its kind for the followers of Buddha dharma (Bhattacharya, 1924). Lord Buddha established the first Bauddha sangha with his first five bhikshus (disciples) and sent them to different directions to spread the teachings of the Buddha dharma (Mazumdar, 1937). Two hundred years after the Mahaparinirvana ${ }^{3}$ of Lord Buddha, King Ashoka built several stupas and erected one inscripted pillar (Hultzsch, 1969). During the Sunga period, Vedica pillars were erected around the stupas (Agrawal, 1966). Many Bodhisattava statues were erected and established during the reign of Kanishka (Agrawal, 1956). Sarnath entered into the golden age of its art and establishment during the Gupta period and the most beautiful status were erected during this period (Sahni, 1972). During the reign of Harshavardhana, the monumental structures of earlier period were rejuvenated, and Rani Kumar Devi, the empress of Govind Chandra Gaharwal, established dharmachakrajin vihara. Fa-Hien and HiuenTsang, both the Chinese pilgrims have mentioned teachings of Buddha, stories related to him, various names of Sarnath and ancient relics of Sarnath.

The description of Chinese traveller is based on two facts. First, they have mentioned the stories related to Lord Gautama Buddha and the Bauddha dharma. It contains the first preaching of Lord Buddha, the establishment of

\footnotetext{
${ }^{3}$ In simple sense, the term Mahaparinirvana refers to the death of Lord Gautama Buddha (Beal, 1980).
} 
Sangha and the story of Mrigajataka, ${ }^{4}$ which are significant even today. Moreover, it also records what they have seen and observed: stupas, pillars, statues, made by the King Ashoka, vihars and monks (bhikshus) living in those vihars, the method of recitation, etc. Indeed, these accounts of Sarnath as sketched by the Chinese travellers help one understand the subtle influence of the Bauddha dharma on various sects and communities. The following figures: 1, 2 and 3 illustrate the artefacts that speak for the teachings of Lord Gautama Buddha's preaching his first discourse.

When it comes to keep abreast with the customary facts of social, educational, historical and traditional knowledge, all the scholars are in sheer agreement with the view that history mirrors the course of a journey, here it refers to the travelling of the Chinese travellers to India that stands significant. With the increased popularity of Bauddha dharma in China, the Chinese were attracted to travel to India. They came to India mainly with the intentions to visit the places related to the fond memories of Buddha, to study the Buddha religion and philosophy and carry the copies of the Buddhist compositions (Chakravarti, 2012). As stated above, Fa-Hien and Hiuen-tsang occupy significant places among these Chinese travellers. They are important not only in relation to the history of the Bauddha dharma but also for illuminating many other subjects. In the said context, in the absence of the details of these pilgrimages, it would have been difficult to understand the state of art of the Bauddha dharma in India during 500-600 A.D. (Pathak, 1990).

\section{Fa-Hien (399-414 A.D.)}

As mentioned already, of the scholarly Chinese travellers, Fa-Hien is the first who visited and presented a contemporary account of India. FaHien visited India during the reign of Gupta emperor, Chandragupta II and lived here for 14-

\footnotetext{
${ }^{4}$ In ancient Indian tales, and in the Buddhist tradition in particular, Mrigajataka narrates the story of Bodhisattva's birth as a deer, which are considered as sacred and enlightening (Cunningham, 1997; Legge, 1971).
}

15 years. The memoirs of the pilgrimage of $\mathrm{Fa}$ hien are contained in 'FO-KYON-KI'. It was translated into English by James Lege, which was published from Oxford as the Record of the Buddhistic Kingdoms. Fa-hien started his journey in China from a place called Si-Gan-Fu. He traversed the desert of Gobi, Khotan, Gandhar, Taxila, Peshawar, Nagardwar, Punjab, Mathura, Sankasya, Kannauj, Saketa, Sravasti, Kapilvastu, Vaishali, Pataliputra to visit Varanasi and Rishipattanmrigdav (Sarnath). Fa-hien again returned to Pataliputra from Varanasi and carried with him the Tamraliptis. ${ }^{5}$ He further travelled through sea route to Ceylon where from he made his return to his own country.

According to him, there lies the Rishipattan Mrigdav (the deer park) at a distance of $10 \mathrm{Li}$ $(6.446 \mathrm{~km})$ (Cunningham, 1997) in the northwest of Varanasi (Legge, 1971). The first sermon (dharma-chakra pravartan) delivered by Lord Buddha to Kaundinya and his four associates after 'Sambodhi' (supreme perfect enlightenment) finds mention in the accounts of Sarnath by Fa-hien, similar to the descriptions found in Tripitaka (Legge, 1971). ${ }^{6}$ According to Fa-hien, there are four stupas and two sangaram where the Buddhist monks lived at that time (Mani, 2006). These accounts of Fahien are clearly supported by the archaeological remains of the Gupta Age. Most of the deities of Lord Buddha during the Gupta Period depict the affluent state of Buddha dharma, when Fahien visited Sarnath.

\section{Hiuen-tsang (629-645 A.D.)}

Hiuen-tsang visited India during the reign of Harshavardhan and lived in India for approximately 15 years. His memories are found in Si-yu-ki. It is believed that Hiuen-tsang himself composed it, but there is a more possibility that this memoir was prepared by one of his disciples on the basis of notes.

\footnotetext{
${ }^{5}$ Tamralipti is the name of an ancient city on the Bay of Bengal believed by scholars to be on the site of Tamluk in modern-day India.

${ }^{6}$ Tripițaka is a Sanskrit word meaning three Baskets. It is the traditional term used by Buddhist traditions to describe their various canons of scriptures.
} 


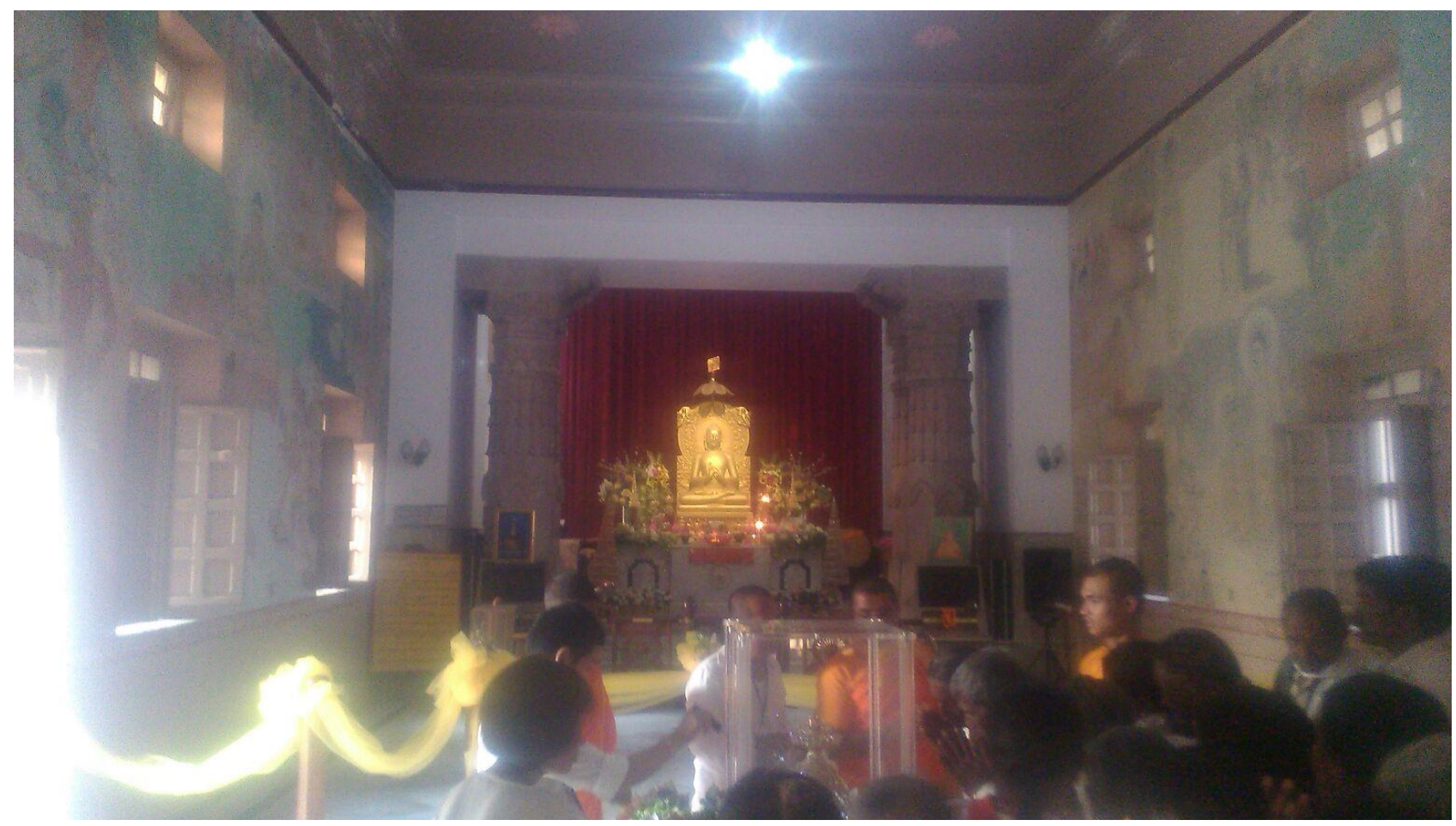

Figure 1: Icon of Lord Gautama Buddha, Sarnath (Source: Author)

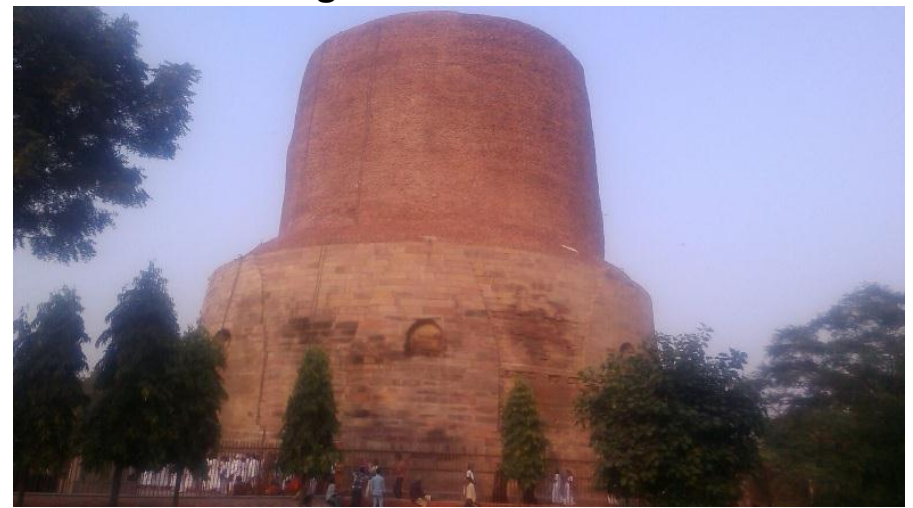

Figure 2: Dhamek Stupa that mark the spot of Deer Park (Rishipattana) in Sarnath

(Source: Author)

Besides this, there lay his biography written by one of his disciples Hui-Li. This paper is however beyond the scope to describe his biography.

Hiuen-tsang travelled from China through Turpha, Kucha, Samarkand, Gandhar, Peshawar, Taxila, Kashmir, Mathura, Sthaneshwar, Kanyakubja, Ayodhya, Prayag, Kausambi, Sravasti and Kushinagar to reach Varanasi. From here, he went to Vaisali, Pataliputra, Bodhgaya, Tamralipti and opted to visit Srilanka via the sea route to study Hinyaan. However, following the teachings of the Monks he declined the idea of travelling through the sea route and instead travelled through Orissa, Andhra and Telugu Pradesh to reach

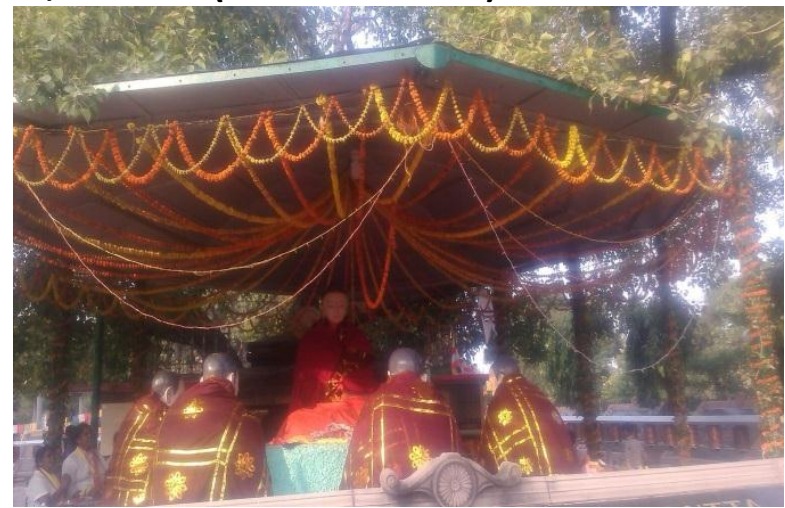

Figure 3: Lord Buddha in Dharmachakrapravartana Posture

(Source: Author)

Kanchipuram, from where he travelled towards north and through Bhrigukachchha, Vallabhi, Sindh, Multan and returned to live in Nalanda. He visited Kamrup on the invitation of Bhaskarvarman and participated in the meetings organised by Harsha at Kannauj and Prayag. He departed from Kannauj to travel through Jalandhar, Taxila, Nagardwar, Kashgar and Khotan to reach China.

Hiuen-tsang, after travelling $500 \mathrm{Li}$ (322.325 $\mathrm{km}$ ) from Kushinagar reached Varanasi (Beal, 1980). According to S-YU-Ki, the Kashi region was spread in the area of $400 \mathrm{Li}(257.860 \mathrm{~km})$ and the capital Varanasi area spread within the length of $18 \mathrm{Li}(11.6 \mathrm{~km})$ and breadth of $5-6 \mathrm{Li}$ $(3.22-3.88 \mathrm{~km})$ on the western bank of the river 
Ganges (Beal, 1980). The city is densely populated with very efficient courteous and sociable people, who revered education and devotion. However, only a part of the population was Buddhist while the rest followed other religions (Beal, 1980). Here, more than 30 Vihars were inhabited by more than 3000 monks of the Sammitiya sect. In addition, there were more than 100 Shaiva temples, who have millions of followersmajority of them are devotees of Lord Shivawhile few of these devotees shave their hairs; few others bear matted hairs; some loiter undraped; few others applies bhasma (a type of human ash) on their bodies-all practice penance to achieve salvation from this mortal world (Beal, 1980). According to Si-Yu-Ki, there was a 100-feet tall statue in one of the temples of Varanasi (Beal, 1980). Accounts of Hiuentsang reveal it clearly that during his visit; the Varanasi town emerged as a significant centre of Shaiva religion.

After Varanasi, Hiuen-Tsang describes Sarnath. In his accounts, there is a 100 -feet high stupa made by King Ashok on the western bank of Varuna towards the north-east of the capital (Beal, 1980). He reached monastery Mrigdav, after travelling $100 \mathrm{Li}(64.46 \mathrm{~km})$ towards north-east of the river Varuna. According to the descriptions, 1500 Buddha monks of Sammitiya branch of Hinyan community lives in sangharam of Mahavihar (monastery) and in the midst of the Vihar there is a large statue of Buddha in the impression of dharmachakrapravartana (the wheel of truth) (Beal, 1980). Hiuen-tsang further describes that there is a stone made stupa erected by Ashoka at the place where Lord Buddha delivered his first sermon, in the south-west Monastery. Although, its base is now displaced, however there remains a wall of almost 100 -feet, with a pillar of approximate height of 70-feet before this wall. This seems to be scintillating with light. It has been believed that those who pray before it, visualise the good or bad signs according as their prayer (Beal, 1980). Currently, the stupa and the pillar respectively designates the dharmarajika stupa and the
Ashoka pillar built in by emperor Ashoka to cherish the relics of Lord Gautama Buddha.

It is believed that Lord Buddha used to meditate nearer to the south of the stupa. This platform is made up of blue stone, which is about 150-feet long and 7-feet high. There lies now the graceful statue of walking Lord Buddha with whirling hairs. Heavenly signs clearly appear upon him, a clear reflection of divinity (Beal, 1980). Further, Hiuen-tsang in his accounts also describe about the deer park (Mrigdav) (please refer to the story of the two deers below) and Rishipattan Vihar, places and events, associated with the Lord Buddha and his life, few of which are noticeable in Sarnath. It contains the stories of attainment of Buddhatva (knowledge) by Matreya Buddha, life of Buddha and stories related with former Buddhas. All these tales signify Lord Gautama Buddha's relations with Rishipattan (Sarnath).

According to Hiuen-tsang, in the monastery premises, there is a pond of fresh water circumscribed by 20 foot-steps. Here, Lord Buddha (also referred to as Tathagat) sometimes used to take bath. To its west, there is another pond with a circumference of 180 foot-steps, where Tathagat used to wash his alms-pot. Towards the north, there is another pond bearing a circumference of 150 foot-steps where Tathagat washed his clothes. The waters of these ponds are deep and stagnant (Beal, 1980). At a short distance from these ponds, there is a stupa in a dense forest, which is famous for the two-deer Buddhist story. The story goes as follows: there lived two kings of deers-Devdatta and Bodhisattava-with their respective dynasties of 500-deer. One day, the King of Kashi was on his deer-hunting mission. Bodhisattava went to the King. He told him: Dear King! you set the forest on fire, and killed my subjects with arrows. I request you to kindly permit me to send one deer everyday so that you may get fresh and pure flesh, which would allow us to live for a little longer. The King was happy with this proposal and returned to his palace. Accordingly, the sacrifice of one deer per day was being followed. One mrigi (doe) was pregnant in the herd of Devadatta. When 
her turn came, she said: I am ready to die but my unborn child should not be the cause of my death. The King Devadatta was angry over it and asked what was the price of life of her child? She replied in agony: $O$ King! to kill the one, who is not born yet won't be humane. Then he (Devadatta) revealed his dilemma to the King Bodhisattava. The king replied: This is certainly a matter of grief. Today, I shall go to die on your place.

Accordingly, when Bodhisattava went to the King of Kashi and narrated the story of the Mrigi, the King of Kashi realised his lack of human qualities of being compassionate and merciful. However, this incident rooted out his callous and brutal qualities-consequently, freed Mrigaraj Bodhisattava and discontinued the event of sacrifice, only to end it. Instead, he created the forest as a sanctuary for deer, only to preserve the mrigas. That is why, the forest was named as Mrigdav (Beal, 1980). Though this story seems merely a didactic story, it relates to the teachings of Buddhist religiosity-a sermon stemming from the teachings of non-violence.

The deliberation of the course of the journey of Hiuen-tsang is vast. Indeed, Hiuen-tsang is the prince of pilgrims (Thakur, 2010). His course of the journey highlights many significant things related to Varanasi and Sarnath. Again, I reiterate that out of these, the growing territory (Singh and Roy, 1986) of the Varanasi city and increasing influence of Shaiva dharma in the city are important (Singh and Roy, 1986). In addition to this, accounts of Hiuen-tsang also describe the decline of the spiritual realm of Buddhism in different parts of India along with Sarnath (Thapar, 2008). There are several theories-both external and internal influences that led to the downfall of Buddhism in India. However, the aim of this paper is only to sketch the religious life in Sarnath.

\section{Conclusion}

The purpose of this paper is to present a sketch of Sarnath and Varanasi as accounted by the Chinese travellers Fa-hien and Hiuen-tsang in the course of their journey. These accounts can be associated with ancient history as well as with historical geography, religion and philosophy. While Fa-hien in his journey details had described about the Buddha empire, and that too in very short, Hiuen-tsang had highlighted the civilisation of India, its culture, landscape in an unbiased manner, albeit it has been often accepted by the historians that these accounts of their journeys should be considered as significant only when they are backed by historical evidences. They opine that these travellers were mainly influenced by the Buddha dharma and therefore, their accounts are liable to containing exaggerated journey details. It is true that journey details contain few imaginary instances but these details are mere historical and genuine or authentic in comparison to contemporary Indian literature, although the structure and nature of these details remain religious. The remnants found from various places, mentioned in these journey details, confirm these facts. Further, the accounts of these two travellers corroborates with the discovery of these historical sites by Alexander Cunningham who conducted geographical research in the 19th century. Thus, it can be said that these journey details occupy a significant place in building various aspects of the ancient Indian history.

\section{References}

Agrawal, Vasudev Saram. (1966). Bharatiya Kala. Prithvi Prakashan: Varanasi.

Agrawal, Vasudev Saran. (1956). Sarnath. Archaeology Survey of India: Delhi.

Beal, Samuel. (1980). Si-Yu-Ki, Buddhist Records of the Western World, Vol.-III. Bharatiya Publishing House: Delhi.

Bhattacharya, B.C. (1924). The History of Sarnath or the Cradle of Buddhism. Tara Printing Works: Banaras.

Chakravarti, Ranabir. (2012). Bhartiya Itihas ka Adikal. Orient Blackswan: Delhi.

Cowel, E.B. (ed.), (1893). Buddhacaritam of Asuaghosa. Clarenton Press: Oxford.

Cunningham, A. (1997). Ancient Geography of India, Vol. I. Indological Book House: Delhi. 
Hultzsch, E. (1969). Corpas Inscriptions Indicarum Inscriptions of Asoka, Vol. I. Archaeological Survey of India: Delhi.

Jayaswal, Vidula. (2011). Adikashi Se Varanasi Tak. Aryan Book International: New Delhi.

Legge, James. (1971). Record of the Buddhistic Kingdoms: Being An Account By the Chinese Monk Fa-hien of His Travels in India and Ceylon. Oriental Publishers: Delhi, First India.

Mani, B.R. (2006). Sarnath: Archaeology, Art and Architecture. Archaeology Survey of India: Delhi.

Majumdar, B.A. (1937). A Guide of Sarnath. Pilgrims Books: Varanasi.

Pathak, Visudhanand. (1990). Panchavee Se Satavee Satabdio Ka Bharat. Sahitya Sangam: Allahabad.

Sahni, D.R. (1972). Catalogue of the Museum of Archaeology at Sarnath. Ideological Book House: Delhi.

Singh, Parasnath and Roy, Janhavi Sekhar. (1986). Videsi Yatriyo ke Dristi Me Banaras. In Thakur Prasad Verma, Devi Prasad Singh, Jayasankar Mishra (eds), Kashi: Through the Ages. Bhartiya Itihas Sankalan Samiti: U.P., p. 341-46.

Thakur, Devendranath (2010). Kashi Me Hiuentsang. In Omprakash Kejariwal (ed.), Kashi Nagari Ek: Rupa Aneka. Publications Division, Ministry of Information \& Broadcasting: New Delhi, p. 37.

Thapar, Romila, (2008). Purva Kalin Bharat (Prarambha Se 1300 AD Tak). Hindi Madhyam Karyanvaya Nidesalaya: Delhi Vishwavidyalaya. 